\title{
Penerapan Fuzzy Inference System Pada Permintaan Darah Di Palang Merah Indonesia Pematangsiantar
}

\author{
Hanifah Urbach Sari1 , Jelly Kartika², Adinda Japa ${ }^{3}$ \\ STIKOM Tunas Bangsa, Pematangsiantar, Indonesia \\ Jl. Jendral Sudirman Blok A No. 1/2/3 \\ Email: hanifaurbachsari@gmail.com
}

\begin{abstract}
Blood donation is the process of channeling blood or blood elements from one person to another's circulatory system. Many people don't know about the benefits of blood donation for health. Even though by making a blood donor, the blood cells in the body become more quickly replaced with new ones. With the increasing demand for blood supply in the community, adequate blood supply is needed. So from that this research was conducted to find out how much the number of blood requests per month by applying the Tsukamoto fuzzy method and having 3 variables, namely donors, supplies, requests. Data taken through the Indonesian Red Cross (PMI) in the city of Pematangsiantar. The results of this study indicate that the Indonesian Red Cross (PMI) Pematangsiantar can make monthly requests for blood more or less is 380 bags of blood.
\end{abstract}

Keywords: Blood donor, Fuzzy Tsukamoto, Pematangsiantar.

Abstrak-Donor darah adalah proses menyalurkan darah atau unsur-unsur darah dari satu orang ke sistem peredaraan orang lainnya. Banyak orang yang tidak tahu tentang manfaat donor darah bagi kesehatan. Padahal dengan melakukan donor darah, maka sel-sel darah di dalam tubuh menjadi lebih cepat terganti dengan yang baru. Dengan meningkatnya permintaan suplai darah di masyarakat, persediaaan darah yang mencukupi sangat dibutuhkan. Maka dari itu penelitian ini dilakukan untuk mengetahui berapa banyakjumlah permintaan darah per bulannya dengan menerapkan metode fuzzy tsukamoto dan memiliki 3 variabel yaitu pendonor, persediaan, permintaan. Data yang diambil melalui Palang Merah Indonesia(PMI) yang ada dikota Pematangsiantar. Hasil dari penelitian ini menunjukkan bahwa Palang Merah Indonesia (PMI) Pematangsiantar dapat melakukan permintaan darah perbulannya kurang lebih adalah 380 kantong darah.

Keywords: Donor darah, Fuzzy Tsukamoto,Pematangsiantar.

\section{PENDAHULUAN}

Donor darah adalah proses menyalurkan darah atau unsur-unsur darah dari satu orang ke sistem peredaraan orang lainnya. Banyak orang yang tidak tahu tentang manfaat donor darah bagi kesehatan. Padahal dengan melakukan donor darah, maka sel-sel darah di dalam tubuh menjadi lebih cepat terganti dengan yang baru. Dengan meningkatnya permintaan suplai darah di masyarakat, persediaaan darah yang mencukupi sangat dibutuhkan. Meskipun demikian, pendonor harus terlebih dahulu menjalani pemeriksaan kesehatan, baik pengukuran tekanan darah, golongan darah, kadar hemoglobin ( $\mathrm{Hb}$ ) maupun konsultasi medis (Depkes RI, 2009)[1]. Kesalahan dalam mempertimbangkan kelayakan calon pendonor 
dapat menimbulkan efek negatif pada kesehatan pendonor setelah mendonorkan darahnya[2].

Seperti yang kita ketahui darah sangat diperlukan dalam tubuh sehingga jika seseorang kekurangan darah maka seseorang itu harus melakukan transfusi darah yang telah disediakan oleh Palang Merah Indonesia (PMI). Darah yang didapat oleh Palang Merah Indonesia(PMI) dari para pendonor darah sukarela dan pendonor darah pengganti. Dalam hal ini orang yang membutuhkan darah tidak kesulitan lagi harus mencari donor darah keluar kota, karena sudah tersedia di Palang Merah Indonesia (PMI) . Penelitian ini dilakukan dikota Pematangsiantar. Tujuan dari penelitian ini adalah untuk mengetahui berapa banyak jumlah permintaan darah per bulannya pada tahunn 2018 di Palang Merah Indonesia(PMI) Kota Pematangsiantar. Dalam permintaan darah per bulan diperlukan suatu metode yang dapat memutuskan permasalahan ini. Metode yang digunakan adalah Metode Fuzzy Tsukamoto. Banyak kelebihan yang dimiliki metode tersebut. Hal ini dibuktikan dengan penelitian yang dilakukan [3] tentang Menentukan kelayakan calon pegawai. Hasil penelitian menunjukkan bahwa metode tersebut mampu menentukan kelayakan calon pegawai dengan metode Fuzzy Inference system Tsukamoto. Berdasarkan perhitungan menggunakan metode Fuzzy Inference system Tsukamoto, menghasilkan nilai keakuratan sebesar 0,952 yang berarti tingkat keakurasian antara pakar dan sistem adalah sangat akurat. Berdasarkan hal tersebut hasil dari penenlitian dapat memberikan informasi kepada Palang Merah Indonesia(PMI) .

\section{METODOLOGI PENELITIAN}

Penelitian ini dilakukan di Palang Merah Indonesia (PMI) dengan lokasi penelitian di kota Pematangsiantar. Metode yang digunakan adalah fuzzy tsukamoto dan memiliki 3 variabel yaitu pendonor, persediaan, dan permintaan.

\subsection{Logika Fuzzy}

Logika fuzzy merupakan perluasan dari teori himpunan klasik. Pada teori himpunan klasik (crisp), keberadaan suatu elemen pada suatu himpunan $A$, hanya akan memiliki 2 kemungkinan keanggotaan, yaitu menjadi anggota $\mathrm{A}$ atau tidak menjadi anggota A. Pada himpunan crisp, nilai keanggotaan ada 2 kemungkinan, yaitu 0 atau 1 . Sedangkan pada himpunan fuzzy nilai keanggotaan terletak pada rentang 0 sampai 1 . Semesta pembicaraan adalah keseluruhan nilai yang diperbolehkan untuk dioperasikan dalam suatu variabel fuzzy[4]. Dalam mendapatkan nilai keanggotaan dengan menggunakan pendekatan fungsi keanggotaan ada beberapa penalaran logika fuzzy[5].

\subsection{Fuzzy Tsukamoto}

Pada metode tsukamoto, setiap konsekuen pada aturan yang berbentuk IFThen harus direpresentasikan dengan suatu himpunan fuzzy dengan fungsi keanggotaan yang menonton sebagai hasilnya, output hasil inferensi dari tiap-tiap aturan diberikan 147

secara tegas (crisp) berdasarkan $\alpha$-predikat (fire strength). Hasil akhirnya di peroleh dengan menggunakan rata-rata terbobot[6]. 


\section{HASIL DAN PEMBAHASAN}

Contoh Kasus :

Palang Merah Indonesia di Pematangsiantar melakukan pendonoran darah dari data tahun 2018, pendonor terbesar mencapai 700 orang dan pendonor terkecil mencapai 200 orang, dan persediaan kantong darah di PMI paling banyak 1400 kantong /bulan dan paling sedikit 700 kantong/bulan, sedangkan PMI hanya memiliki permintaan paling banyak 700 kantong/bulan dan paling sedikit 300 kantong/bulan.

- Jika pendonor sedikit dan persediaan banyak maka permintaan sedikit

- Jika pendonor sedikit dan persediaan sedikit maka permintaan sedikit

- Jika pendonor banyak dan persediaan banyak maka permintaan banyak

- Jika pendonor banyak dan persediaan sedikit maka permintaan banyak

Berapa permintaan kantong darah jika jumlah pendonor 600 orang dan persediaan 500 kantong/bulan?

Diketahui :

$$
\begin{aligned}
& x=\text { pendonor }[\text { sedikit } ; \text { banyak }] \\
& y=\text { persediaan }[\text { sedikit } ; \text { banyak }] \\
& z=\text { permintaan }[\text { sedikit } ; \text { banyak }] \\
& x=[200 ; 700] \\
& y=[500 ; 1400] \\
& z=[300 ; 400]
\end{aligned}
$$

Ditanya :

$$
\begin{aligned}
& x=600 \\
& y=500 \\
& z=?
\end{aligned}
$$

- $\quad$ if $x=$ sedikit And $y=$ banyak Then $z=$ sedikit

- $\quad$ if $x=$ sedikit And $y=$ sedikit Then $z=$ sedikit

- if $x=$ banyak And $y=$ banyak Then $z=$ banyak

- if $x=$ banyak And $y=$ sedikit Then $z=$ banyak

Penyelesaian :

a. Pendonor $(X)=600$

$$
\begin{aligned}
\mu_{x}(\text { sedikit }) & =\frac{b-x}{b-a} \\
& =\frac{700-600}{700-200} \\
& =\frac{100}{500}=0,2 \\
\mu_{y}(\text { banyak }) & =\frac{x-a}{b-a} \\
& =\frac{600-200}{700-200}
\end{aligned}
$$

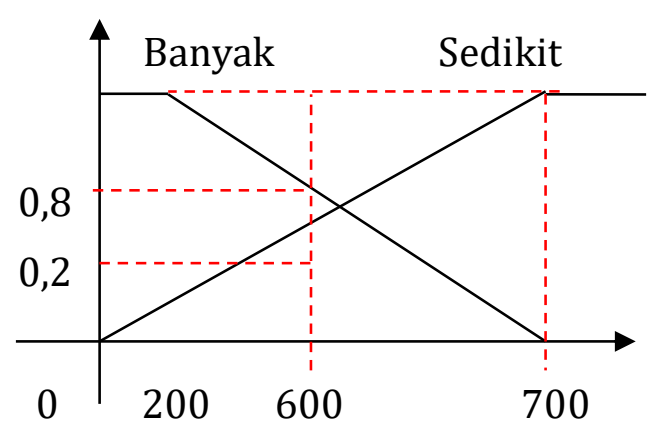




$$
=\frac{400}{500}=0,8
$$

\section{b. Persediaan $(Y)=500$}

$$
\begin{aligned}
\mu_{x}(\text { banyak }) & =\frac{x-a}{b-a} \\
& =\frac{500-500}{1400-500} \\
& =\frac{0}{900}=0 \\
\mu_{y}(\text { sedikit }) & =\frac{b-x}{b-a} \\
& =\frac{1400-500}{1400-500} \\
& =\frac{900}{900}=1
\end{aligned}
$$

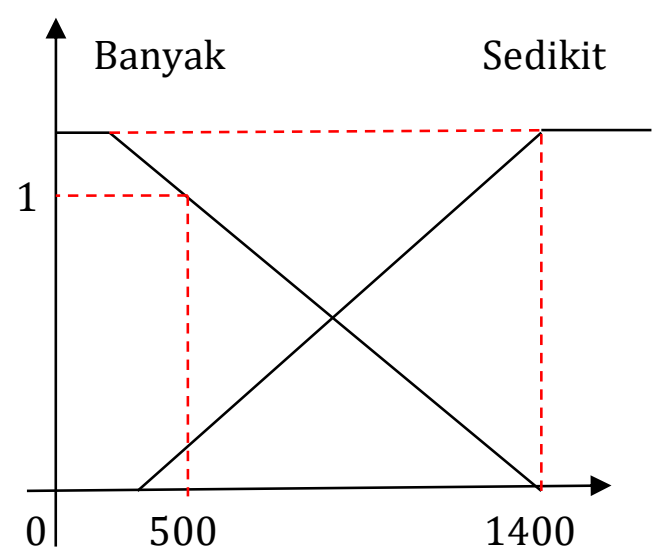

\section{c. Permintaan (Z)}

\section{RULE 1:}

$\alpha$-predikat $=\mu_{x[\text { sedikit }]} \cap \mu_{y[\text { banyak }]}$ then $z=$ sedikit

$\alpha-$ predikat $=\min [0,2 ; 0]$

$\alpha-$ predikat $=0$

$$
\begin{aligned}
z_{[\text {sedikit }]} & =\frac{b-x}{b-a} \\
0 & =\frac{400-x}{400-300} \\
0 & =\frac{400-x}{100} \\
400-x & =0 * 100 \\
400-x & =0 \\
-x & =0-400 \\
-x & =-400 \\
x & =400
\end{aligned}
$$

RULE 2:

$\alpha$-predikat $2=\mu_{x[\text { sedikit }]} \cap \mu_{y[\text { sedikit }]}$ then $z=$ sedikit

$\alpha-$ predikat $2=\min [0,2 ; 1]$

$\alpha-$ predikat $2=0,2$

$$
\begin{aligned}
z_{[\text {sedikit }]} & =\frac{b-x}{b-a} \\
0,2 & =\frac{400-x}{400-300} \\
0,2 & =\frac{400-x}{100} \\
400-x & =0,2 * 100
\end{aligned}
$$




$$
\begin{aligned}
400-x & =20 \\
-x & =20-400 \\
-x & =-380 \\
x & =380
\end{aligned}
$$

RULE 3:

$\alpha$-predikat $3=\mu_{x[\text { banyak }]} \cap \mu_{y[\text { banyak }]}$ then $z=$ banyak $\alpha-$ predikat $3=\min [08 ; 0]$

$\alpha-$ predikat $3=0,2$

$$
\begin{aligned}
z_{\text {[banyak }]} & =\frac{x-a}{b-a} \\
0 & =\frac{x-300}{400-300} \\
0 & =\frac{x-300}{100} \\
x-300 & =0 * 100 \\
x-300 & =0 \\
x & =0+300 \\
x & =300
\end{aligned}
$$

RULE 4:

$\alpha-$ predikat $4=\mu_{x[\text { banyak }]} \cap \mu_{y[\text { sedikit }]}$ then $z=$ banyak

$\alpha$-predikat $4=\min [0,8 ; 1]$

$\alpha-$ predikat $4=0,8$

$$
\begin{aligned}
z_{[\text {banyak }]} & =\frac{x-a}{b-a} \\
0,8 & =\frac{x-300}{400-300} \\
0,8 & =\frac{x-300}{100} \\
x-300 & =0,8 * 100 \\
x-300 & =80 \\
x & =80+300 \\
x & =380 \\
z & =\frac{(\alpha \text { pre } 1 * z 1)+(\alpha \text { pre } 2 * z 2)+(\alpha \text { pre } 3 * z 3)+(\alpha \text { pre } 4 * z 4)}{z 1+z 2+z 3+z 4} \\
z & =\frac{(400 * 0)+(380 * 0,2)+(300 * 0)+(380 * 0,8)}{0+0,2+0+0,8} \\
z & =\frac{76+304}{1} \\
z & =\frac{380}{1} \\
z & =380
\end{aligned}
$$


Jadi menurut perhitungan, Palang Merah Indonesia (PMI) Pematangsiantar dapat melakukan permintaan darah perbulannya adalah 380 kantong darah.

\section{KESIMPULAN}

Berdasarkan penelitian tersebut dapat dijelaskan bahwa metode fuzzy tsukamoto dapat diterapkan pada permintaan darah di Palang Merah Indonesia (PMI) di Pematangsiantar. Hasil penelitian menunjukkan dari 3 variabel yang digunakan (pendonor, persediaan, permintaan) menyebutkan bahwa permintaan darah perbulannya adalah 380 kantong darah

\section{DAFTAR PUSTAKA}

[1] D. Bayususetyo, R. Santoso, and Tarno, "KLASIFIKASI CALON PENDONOR DARAH MENGGUNAKAN METODE NAÏVE BAYES CLASSIFIER (Studi Kasus : Calon Pendonor Darah di Kota Semarang)," J. GAUSSIAN, vol. 6, no. 2, pp. 193-200, 2017.

[2] P. Studi, T. Informatika, F. I. Komputer, U. D. Nuswantoro, and L. B. Masalah, "Sistem pendukung keputusan kelayakan pendonor darah menggunakan fuzzy multiple citeria decision analysis (f-mcda) timoer dwi hapsoro."

[3] N. R. Sari and W. F. Mahmudy, "Fuzzy Inference System Tsukamoto Untuk Menentukan Kelayakan Calon Pegawai," Semin. Nas. Sist. Inf. Indones., no. November, pp. 2-3, 2015.

[4] Jasri, "Fuzzy Logic Tsukamoto untuk Menentukan Jenis Penyakit Hipertensi dengan Golongan Obat Yang Sesuai," Riau J. Comput. Sci., vol. 4, no. 1, pp. 69-84, 2017.

[5] M. Yusida, D. Kartini, R. A. Nugroho, and M. Muliadi, "Implementasi Fuzzy Tsukamoto Dalam Penentuan Kesesuaian Lahan Untuk Tanaman Karet Dan Kelapa Sawit," Klik - Kumpul. J. Ilmu Komput., vol. 4, no. 2, p. 233, 2018.

[6] M. Mesterjon, Maryaningsih, "Metode Logika Fuzzy Tsukamoto Dalam Sistem Pengambilan," Metod. Log. Fuzzy Tsukamoto Dalam Sist. Pengambilan Keputusan Penerimaan Beasiswa, vol. 9 , no. 1 , pp. $140-165,2013$. 